\title{
PENGENDALIAN HAMA Spodoptera exigua Hubner. PADA TANAMAN BAWANG MERAH VARIETAS LEMBAH PALU DENGAN PENGGUNAAN PUPUK DAN MULSA
}

\author{
Controlling Spodoptera exigua Hubner. On Shallot Using Fertilizers and Mulches
}

\author{
Valentino $^{1)}$, Abd. Rahim Thaha ${ }^{1)}$ \\ 1) Program Studi Agroteknologi Fakultas Pertanian Universitas Tadulako.
}

\begin{abstract}
This study aimed to determine the effect of fertilizer and mulch on the intensity attack of $S$. exigua and the yield of Lembah Palu shallot variety. The research was conducted in Bolu Pountu Jaya, Sigi Village, District of Sigi Biromaru, Sigi Regency, from September to November 2013. The study design was a two-factorial randomized pattern with three replicates for each experimental unit. The first factor was various types of mulch consisted of four treatment without mulch (M0), rice straw mulch (M1), cocoa mulch (M2) and plastic mulch (M3). The second factor was different kinds of fertilizers including liquid organic fertilizer (P1), guano fertilizer (P2) and synthetic fertilizer (P3). There is no significant interaction effect between the type of fertilizers and mulch on the intensity of S. exigua and shallot yields. However, the individual effect of the mulches was significant on reducing the intensity of $S$. exigua attack and increasing the yield of the shallot. The rice straw mulch reduced the attack intensity of $S$. exigua by $20.83 \%$, whereas the cacao mulch increased the yield by $47.61 \%$ compared to the control treatment.
\end{abstract}

Keywords : Fertilizer, Lembah Palu shallot, mulch and Spodoptera exigua.

\begin{abstract}
ABSTRAK
Penelitian ini bertujuan untuk mengetahui pengaruh pemberian pupuk dan mulsa terhadap intensitas S. exigua dan hasil varietas bawang merah Lembah Palu. Penelitian ini dilaksanakan di Bolu Pountu Jaya, Desa Sigi, Kecamatan Sigi Biromaru, Kabupaten Sigi, dari bulan September hingga November 2013. Penelitian ini menggunakan pola faktorial dengan dua faktor. Faktor pertama adalah penggunaan berbagai jenis mulsa yang terdiri dari empat perlakuan yaitu Tanpa Mulsa (M0), Mulsa Jerami Padi (M1), Mulsa Kakao (M2) dan Mulsa Plastik (M3). Sedangkan faktor kedua adalah berbagai jenis pupuk terdiri dari tiga perlakuan. Pupuk cair organik (P1), pupuk quano (P2) dan pupuk sintetis (P3). Setiap perlakuan diulang sebanyak tiga kali sehingga terdapat 36 perlakuan. Hasil penelitian menunjukkan bahwa tidak ada pengaruh pada berbagai jenis pupuk dan mulsa terhadap intensitas $S$. exigua dan jumlah hasil bawang merah. Aplikasi berbagai jenis mulsa berpengaruh signifikan terhadap intensitas $S$. exigua. Penggunaan mulsa jerami padi mampu mengurangi intensitas S. exigua sebesar 20,83\%, sedangkan penggunaan mulsa kulit kakao meningkatkan hasil bawang merah sebesar $47,61 \%$.
\end{abstract}

Kata Kunci : Bawang Merah Lembah Palu, Spodoptera exigua, Pupuk dan Mulsa 


\section{PENDAHULUAN}

Bawang merah (Allium ascalonicum L.) merupakan salah satu jenis sayuran umbi yang penting dan dikonsumsi sebagai bumbu penyedap masakan. (Wongmekiat, Leelarugrayub, and Thamprasert 2008; Raeisi et al. 2016) Komoditas ini banyak diusahakan oleh petani di Kabupaten Donggala terutama di Lembah Palu sehingga biasa disebut bawang merah Palu. Penggunaan nama ini kemudian diresmikan oleh Gubernur Sulawesi Tengah pada acara perayaan Hari Krida Pertanian tahun 2000 di Palu. Sama halnya dengan bawang merah lokal lainnya seperti bawang merah Sumenep dan Bima.

Hasil rata-rata bawang merah di tingkat petani dengan budidaya tradisional baru mencapai 3 t/ha (Mustafa and Komatsu 2016; Haque et al. 2014), sedangkan dengan menggunakan teknologi budidaya yang sesuai, hasilnya bisa ditingkatkan menjadi 11,10 t/ha (Limbongan, J. dan A. Monde. 1999., Maskar et al., 2001). Sebagai pembanding, hasil bawang merah Ampenan di daerah pasang surut bisa mencapai 4,70 7,60 t/ha (Sutater et al., 1990) dan di lahan irigasi sekitar 10-20 t/ha (Satsijati dan Koswara, 1993).

Pengendalian terhadap $S$. exigua oleh petani sampai saat ini masih menggunakan insektisida 2-3 hari sekali, bahkan petani mencampurbeberapa jenis pestisida dalam satu kali aplikasi. (Ahmad, Farid, and Saeed 2018; Tarnawska et al. 2019) Teknik ini walaupun mampu menekan serangan $S$. exigua, tetapi tindakan tersebut tidak bisa dilakukan secara terus menerus karena dapat menyebabkan terjadinya resistensi dan resurgensi hama $S$. exigua terhadap insektisida dan bisa berdampak buruk terhadap kesehatan manusia dan lingkungan (Wang et al. 2018; Nunes et al. 2013)

Hasil survai Pasaru (1999), menunjukkan bahwa 95\% responden yang melakukan pengendalian hama pada tanaman sayuran di Kabupaten Donggala ternyata masih mengandalkan pestisida.
Petani biasanya menggunakan pestisida dengan cara mencampur 2-4 jenis pestisida untuk setiap kali penyemprotan dan dilakukan 2-3 kali dalam satu minggu. Sejalan dengan semakin tingginya pemakaian pestisida pada pertanaman sayuran, dikhawatirkan residu pestisida pada sayuran sudah melampaui batas toleransi (Winter and Jara 2015; Parrilla Vázquez et al. 2019)

Pengkajian dan pengembangan teknik pengendalian alternatif dalam kerangka pengendalian terpadu terhadap hama $S$. Exigua perlu dilakukan untuk mendapatkan cara pengendalian yang lebih murah, mudah didapatkan dan aman terhadap lingkungan (Saeed et al. 2019; Chen et al. 2019). Untuk mengurangi praktek penggunaan pestisida secara tidak bijaksana dikalangan petani maka pemerintah telah menetapkan Undang-Undang No.12 tahun 1992 tentang sistem budidaya tanaman dan Peraturan Pemerintah Nomor 6 Tahun 1995 tentang Perlindungan Tanaman.

Konsep ini merekomendasikan perpaduan lima teknik pengendalian yang dikenal dengan pengendalian hama terpadu (PHT) yaitu: (1) Membudidayakan tanaman sehat, (2) memanfaatkan sebesar-besarnya musuh alami, (3) menggunakan varietas tahan, (4) menggunakan pengendalian fisik/mekanik dan (5) penggunaan pestisida bila dianggap perlu. (Githiomi et al. 2019; Gautam et al. 2017)., (Saeed et al, 2019) Oleh karena itu penelitian ini berorientasi pada upaya penerapan konsep PHT untuk pengendalian hama $S$. exigua. (Muriithi et al. 2016; Kalmar et al. 2014)

Tujuan umum dari penelitian ini adalah untuk mengetahui pengaruh mulsa dan pupuk terhadap intensitas serangan hama $S$. exigua dan peningkatan hasil bawang merah varietas lembah Palu, sedangkan tujuan khusus dari penelitian ini adalah mengetahui interaksi penggunaan berbagai jenis mulsa dan pupuk terhadap intensitas serangan hama $S$. exigua dan hasil bawang merah.

\section{METODE PENELITIAN}

Penelitian dilaksanakan di areal perkebunan petani yang berada di 
Lingkungan Bolu Pountu Jaya, Desa Sigi, Kecamatan Sigi Biromaru, Kabupaten Sigi. Kegiatan penelitian ini berlangsung dari bulan September sampai bulan November 2013.

Bahan yang digunakan dalam penelitian ini adalah benih bawang merah varietas lembah Palu yang sudah siap tanam, pupuk organik cair (merk dagang Zeo 16), pupuk guano (merek dagang micro karet plus) dan pupuk sintetis (merek dagang syahdana agro analitika), limbah jerami padi kering, limbah kulit kakao kering dan mulsa plastik hitam perak.

Alat yang digunakan dalam penelitian ini adalah Cangkul, Sabit, Traktor, Kertas Label, Timbangan Analitik, Kalkulator, Baki Plastik, Penggaris dan Knapsack Spayer.

Rancangan dan Perlakuan. Penelitian dirancang dengan menggunakan rancangan Acak Kelompok Faktorial (RAK) (Lu, Jiannan, and Alex Deng. 2017). Dasar pengelompokan adalah ukuran benih bawang merah siap tanaman. Untuk memperkecil pengaruh keragaman faktor lingkungan, maka satuan-satuan percobaan di tempatkan ke dalam 3 (tiga) kelompok sekaligus berfungsi sebagai ulangan. Perlakuan terdiri atas dua faktor yaitu faktor pertama pemberian mulsa (M) yang terdiri atas empat perlakuan yaitu :

M0 : Kontrol (Tanpa Mulsa)

M1 : Limbah jerami padi sebanyak 4,5 $\mathrm{kg} /$ petak perlakuan (Purwowidodo, 1982)

M2 : Limbah kulit kakao sebanyak 9 $\mathrm{kg} /$ petak perlakuan (Soedarsono et al, 1997)

M3 : Mulsa plastik $(1,5 \mathrm{~m}$ x 2,0 m)

Sedangkan faktor kedua adalah pemberian pupuk $(\mathrm{P})$ dengan tiga perlakuan yaitu:

P1 : Pupuk organik cair sebanyak 7,5 $\mathrm{ml} /$ liter air

P2 : Pupuk guano sebanyak 150 gram/petak perlakuan

P3 : Pupuk sintetis sebanyak 60 gram/petak perlakuan

Setiap perlakuan diulang sebanyak 3 (tiga) kali, sehingga terdapat 36 perlakuan.
Pelaksanaan Penelitian. Penanaman dilakukan pada tanah yang sebelumnya telah ditanami jagung. Petak-petak perlakuan dibuat dengan ukuran $1,5 \mathrm{~m}$ x 2,0 m. Jarak antar petak $0,4 \mathrm{~m}$ dan jarak antar blok atau ulangan $0,75 \mathrm{~m}$. Penanaman benih bawang dilakukan pada kedalaman $1 \mathrm{~cm}$ di bawah permukaan tanah, dengan satu benih per lubang, benih ditanam berdasarkan ukuran benih bawang yang sudah dikelompokan. Jarak tanam yang digunakan yaitu $15 \mathrm{~cm} \mathrm{x}$ $20 \mathrm{~cm}$.

Pemasangan mulsa dilakukan 1 (satu) minggu setelah tanam. Pemasangan mulsa jerami padi dengan cara menebar di atas bedengan perlakuan begitu pula dengan pemasangan mulsa kulit kakao dengan cara menebar di atas bedengan sesuai dengan jumlah yang digunakan. Sedangkan pemasangan mulsa plastik dengan cara menancapkan bambu yang sudah dibelah pada kedua ujung mulsa plastik kemudian menarik mulsa plastik sesuai dengan panjang bedengan secara perlahan agar mulsa tidak terlipat dan robek. sedangkan aplikasi pupuk perlakuan setelah tanaman berumur dua minggu dengan cara menaburkan pada setiap tanaman perlakuan sesuai dengan dosis perlakuan.

Tanaman Sampel. Penentuan tanaman sampel dilakukan secara sistematis mengikuti pola huruf $\mathrm{U}$ dengan jumlah tanaman yang diamati sebanyak 10 (sepuluh) rumpun tanaman/petak. Tanaman pinggir tidak digunakan sebagai tanaman sampel. Pengamatan dilakukan setiap minggu, sejak tanaman berumur 2 (dua) minggu setelah tanam hingga panen.

Variabel Pengamatan. Variabel yang diamati dalam penelitian ini adalah:

1) Intensitas Serangan Hama S. exigua

Penentuan intensitas serangan hama S.exigua pada tanaman bawang merah dihitung menggunakan rumus serangan mutlak yaitu (djojosumarto,2000) :

$$
\mathrm{P}=\frac{a}{b} \chi 100 \%
$$

Keterangan :

$\mathrm{P}$ : Persentase kerusakan 
a : Jumlah anakan yang terserang

b : Jumlah anakan yang diamati

Pengamatan intensitas serangan

S.exigua dengan cara mengamati 10

(sepuluh) rumpun tanaman sampel yang

sudah di tentukan, yang diamati setiap interval 7 (tujuh) hari (satu minggu) jika terdapat tanaman yang terserang maka tanaman tersebut dianggap sudah tidak efektif (mati).

2) Jumlah Anakan Tanaman Bawang Merah

Pengamatan jumlah anakan pada tanaman bawang merah dilakukan pada saat tanaman bawang berumur 14 (empat belas) hari setelah tanam sampai dengan 1 (satu) minggu sebelum panen yang diamati setiap 1 (satu) minggu. Dengan cara menghitung jumlah 10 (sepuluh) rumpun tanaman sampel yang sudah ditentukan kemudian mencatat hasil pengamatan.

3) Tinggi Tanaman Bawang Merah

Pengamatan tinggi daun tanaman diukur menggunakan penggaris dengan cara mengukur dari pangkal daun tanaman sampai ujung daun tanaman. Dalam 10 (sepuluh) rumpun tanaman sampel ditentukan 1 (satu) daun yang paling tinggi yang dijadikan sebagai hasil pengamatan. Pengukuran tinggi daun tanaman dilakukan 1 (satu) minggu sebelum panen.

4) Bobot Umbi Bawang Merah

Pengamatan bobot umbi bawang merah dengan cara menimbang bobot umbi basah dari 10 (sepuluh) rumpun tanaman sampel masing-masing perlakuan yang diamati pada saat panen atau 8 (delapan) minggu setalah tanam sedangkan pengamatan bobot umbi kering dilakukan setelah umbi bawang merah dikering anginkan selama 1 (satu) minggu. Pengeringan umbi dilakukan dengan cara menggantung umbi bawang merah pada tempat yang sudah di tentukan (Nielsen et al. 2016)

Analisis Data. Analisis data yang digunakan dalam penelitian ini adalahanalisis ragam (ANOVA) sesuai dengan rancangan dan pola percobaan yang digunakan yaitu RAK Faktorial (RAKF), dengan uji beda rata-rata perlakuan dengan BNJ 5\% (Balaram Naik and Chennakeshava Reddy 2018; Rossi and Mirtchev 2016)

\section{HASIL DAN PEMBAHASAN}

\section{Intensitas Serangan Hama $S$. exigua} Pada Tanaman Bawang Merah. Analisis ragam menunjukkan bahwa perlakuan mulsa (M) berpengaruh nyata terhadap intensitas serangan hama $S$. exigua pada pengamatan 8 MST. Pemberian pupuk (P) serta interaksi (MP) tidak berpengaruh nyata terhadap intensitas serangan hama $S$. exigua pada setiap minggu pengamatan.

Perlakuan mulsa (M) yang menunjukan pengaruh nyata terhadap intensitas serangan hama $S$. exigua pada pengamatan 8 MST, ditunjukan pada Tabel 1.

Tabel 1. Intensitas Serangan Hama S. exigua pada Tanaman Bawang Merah Pengamatan 8 MST (\%)

\begin{tabular}{|c|c|c|c|c|c|c|}
\hline \multirow{2}{*}{ Faktor P } & \multicolumn{4}{|c|}{ Faktor M } & \multirow{2}{*}{ Jumlah } & \multirow{2}{*}{ Rata-rata } \\
\hline & MO & M1 & M2 & M3 & & \\
\hline P1 & 2,0 & 2,0 & 3,3 & 2,7 & 10,0 & 2,5 \\
\hline P2 & 2,7 & 2,3 & 3,7 & 3,3 & 12,0 & 3,0 \\
\hline P3 & 2,7 & 1,3 & 3,0 & 3,7 & 10,7 & 2,7 \\
\hline Total & 7,3 & 5,7 & 10,0 & 9,7 & 32,7 & 8,2 \\
\hline Rata-rata & $2,4^{\mathrm{a}}$ & $1,9^{\mathrm{a}}$ & $3,3^{\mathrm{b}}$ & $3,2^{\mathrm{b}}$ & 10,9 & 2,7 \\
\hline BNJ & 1,315 & & & & & \\
\hline
\end{tabular}

Keterangan : Angka-angka yang diikuti huruf yang sama pada baris yang sama tidak berbeda nyata pada uji BNJ (0.05) 
Hasil uji BNJ pada taraf 5\% (Tabel 1), menunjukkan bahwa intensitas serangan $S$. exigua terendah terjadi pada perlakuan mulsa jerami padi $(\mathrm{M} 1=1,9 \%)$, tidak berbeda nyata dengan perlakuan tanpa mulsa $(\mathrm{M} 0=2,4 \%)$, tetapi berbeda nyata dengan perlakuan mulsa kulit kakao $(\mathrm{M} 2=3,3 \%)$ dan perlakuan mulsa plastik $(\mathrm{M} 3=3,2 \%)$, ini berarti bahwa penggunaan mulsa jerami padi dapat menurunkan intensitas serangan $S$. exigua secara nyata.

\section{Jumlah Anakan Tanaman Bawang}

Merah. Analisis ragam menunjukkan bahwa perlakuan mulsa (M) berpengaruh nyata terhadap jumlah anakan tanaman bawang merah pada pengamatan 8 MST. Pemberian pupuk (P) serta interaksi (MP) tidak berpengaruh nyata terhadap jumlah anakan tanaman bawang merah.

Perlakuan mulsa (M) yang menunjukan pengaruh nyata terhadap jumlah anakan tanaman bawang merah pada pengamatan 8 MST, ditunjukan pada Tabel 2.

Hasil uji BNJ pada taraf 5\% (Tabel

2), menunjukkan bahwa jumlah anakan tanaman bawang merah terbanyak terjadi pada perlakuan mulsa kulit kakao (M2=10,8/ rumpun), tidak berbeda nyata dengan perlakuan mulsa kontrol
( $\mathrm{MO}=10,2 /$ rumpun) dan mulsa plastik (M3=9,0/rumpun), tetapi berbeda nyata dengan perlakuan mulsa jerami padi (M1=7,0/rumpun), ini berarti bahwa penggunaan mulsa kulit kakao dapat memperbanyak jumlah anakan tanaman bawang merah secara nyata.

Tinggi Tanaman Bawang Merah. Analisis ragam menunjukkan bahwa perlakuan mulsa (M) berpengaruh nyata terhadap tinggi daun tanaman bawang merah. Pemberian pupuk (P) serta interaksi (MP) tidak berpengaruh nyata terhadap jumlah anakan tanaman bawang merah.

Perlakuan mulsa (M) yang menunjukan pengaruh nyata terhadap tinggi daun tanaman bawang merah, ditunjukan pada Tabel 3.

Hasil uji BNJ pada taraf 5\% (Tabel 2), menunjukkan bahwa tinggi tanaman bawang merah tertinggi terjadi pada perlakuan mulsa kulit kakao $(\mathrm{M} 2=25,4 \mathrm{~cm})$, berbeda nyata dengan perlakuan mulsa jerami padi $(\mathrm{M} 1=18,3 \mathrm{~cm})$, mulsa plastik $(\mathrm{M} 3=17,3)$ dan tanpa mulsa $(\mathrm{M} 0=18,3 \mathrm{~cm})$, ini berarti bahwa penggunaan mulsa kulit kakao dapat meningkatkan tinggi tanaman bawang merah secara nyata.

Tabel 2. Rata-Rata Jumlah Anakan Per Rumpun Tanaman Bawang Merah Pengamatan 8 MST

\begin{tabular}{|c|c|c|c|c|c|c|}
\hline \multirow{2}{*}{ Faktor P } & \multicolumn{4}{|c|}{ Faktor M } & \multirow{2}{*}{ Jumlah } & \multirow{2}{*}{ Rata-rata } \\
\hline & $\mathrm{MO}$ & M1 & M2 & M3 & & \\
\hline $\mathrm{P} 1$ & 10,2 & 7,0 & 11,1 & 8,7 & 37,0 & 9,2 \\
\hline $\mathrm{P} 2$ & 8,9 & 6,0 & 9,7 & 8,9 & 33,6 & 8,4 \\
\hline P3 & 11,5 & 8,1 & 11,5 & 9,4 & 40,4 & 10,1 \\
\hline Total & 30,6 & 21,1 & 32,3 & 27,0 & 111,0 & 27,8 \\
\hline Rata-rata & $10,2^{\mathrm{b}}$ & $7,0^{\mathrm{a}}$ & $10,8^{\mathrm{b}}$ & $9,0^{\mathrm{b}}$ & 37,0 & 9,3 \\
\hline BNJ & 3,407 & & & & & \\
\hline
\end{tabular}

Keterangan : Angka-angka yang diikuti huruf yang sama pada baris yang sama tidak berbeda nyata pada uji BNJ (0.05) 
Tabel 3. Rata-Rata Tinggi Tanaman Bawang Merah (cm).

\begin{tabular}{|c|c|c|c|c|c|c|}
\hline \multirow{2}{*}{ Faktor P } & \multicolumn{4}{|c|}{ Faktor M } & \multirow{2}{*}{ Jumlah } & \multirow{2}{*}{ Rata-rata } \\
\hline & $\mathrm{MO}$ & M1 & M2 & M3 & & \\
\hline P1 & 17,1 & 18,2 & 24,4 & 19,4 & 79,1 & 19,8 \\
\hline $\mathrm{P} 2$ & 18,0 & 17,6 & 23,4 & 13,7 & 72,8 & 18,2 \\
\hline P3 & 19,9 & 19,2 & 28,4 & 18,9 & 86,3 & 21,6 \\
\hline Total & 55,0 & 55,0 & 76,2 & 51,9 & 238,1 & 59,5 \\
\hline Rata-rata & $18,3^{\mathrm{b}}$ & $18,3^{\mathrm{b}}$ & $25,4^{\mathrm{a}}$ & $17,3^{\mathrm{b}}$ & 79,4 & 19,8 \\
\hline $\mathrm{BNJ}$ & 7,52 & & & & & \\
\hline
\end{tabular}

Keterangan: Angka-angka yang diikuti huruf yang sama pada baris yang sama tidak berbeda nyata pada uji BNJ (0.05)

Tabel 4. Rata-Rata Bobot Umbi Basah Tanaman Bawang Merah (g/rumpun)

\begin{tabular}{|c|c|c|c|c|c|c|}
\hline \multirow{2}{*}{ Faktor P } & \multicolumn{4}{|c|}{ Faktor M } & \multirow{2}{*}{ Jumlah } & \multirow{2}{*}{ Rata-rata } \\
\hline & MO & M1 & M2 & M3 & & \\
\hline P1 & 100,0 & 119,0 & 150,0 & 119,0 & 488,0 & 122,0 \\
\hline $\mathrm{P} 2$ & 115,0 & 119,7 & 177,0 & 116,7 & 528,3 & 132,1 \\
\hline P3 & 119,0 & 119,0 & 166,0 & 119,0 & 523,0 & 130,8 \\
\hline Total & 334,0 & 357,7 & 493,0 & 354,7 & 1539,3 & 384,8 \\
\hline Rata-rata & $111,3^{b}$ & $119,2^{b}$ & $164,3^{\mathrm{a}}$ & $118,2^{b}$ & 513,1 & 128,3 \\
\hline
\end{tabular}

Keterangan : Angka-angka yang diikuti huruf yang sama pada baris yang sama tidak berbeda nyata pada uji BNJ (0.05)

Tabel 5. Rata-Rata Bobot Umbi Kering Tanaman Bawang Merah (g/rumpun).

\begin{tabular}{|c|c|c|c|c|c|c|}
\hline \multirow{2}{*}{ Faktor P } & \multicolumn{4}{|c|}{ Faktor M } & \multirow{2}{*}{ Jumlah } & \multirow{2}{*}{ Rata-rata } \\
\hline & $\mathrm{MO}$ & M1 & M2 & M3 & & \\
\hline P1 & 86,7 & 99,0 & 130,0 & 99,0 & 414,7 & 103,7 \\
\hline $\mathrm{P} 2$ & 95,0 & 99,7 & 157,0 & 96,7 & 448,3 & 112,1 \\
\hline P3 & 99,0 & 99,0 & 146,0 & 99,0 & 443,0 & 110,8 \\
\hline Total & 280,7 & 297,7 & 433,0 & 294,7 & 1306,0 & 326,5 \\
\hline Rata-rata & $93,6^{\mathrm{b}}$ & $99,2^{\mathrm{b}}$ & $144,3^{\mathrm{a}}$ & $98,2^{\mathrm{b}}$ & 435,3 & 108,8 \\
\hline BNJ & 24,531 & & & & & \\
\hline
\end{tabular}

Keterangan: Angka-angka yang diikuti huruf yang sama pada kolom yang sama tidak berbeda nyata pada uji BNJ (0.05). 
Bobot Umbi Tanaman Bawang Merah. Analisis ragam menunjukkan bahwa perlakuan mulsa $(\mathrm{M})$ berpengaruh nyata terhadap bobot umbi tanaman bawang merah. Pemberian pupuk (P) serta interaksi (MP) tidak berpengaruh nyata terhadap bobot umbi tanaman bawang merah.

Perlakuan mulsa (M) yang menunjukan pengaruh nyata terhadap bobot umbi basah tanaman bawang merah, ditunjukan pada Tabel 4.

Hasil uji BNJ pada taraf 5\% (Tabel 2), menunjukkan bahwa bobot umbi basah tanaman bawang merah tertinggi terjadi pada perlakuan mulsa kulit kakao (M2=164,3 g/rumpun), berbeda nyata dengan perlakuan tanpa mulsa $(\mathrm{M} 0=113,3$ g/rumpun), mulsa jerami padi (M1=119,2 g/rumpun) dan perlakuan mulsa plastik (M3=118,2 g/rumpun), ini berarti bahwa penggunaan mulsa kulit kakao dapat menghasilkan bobot umbi yang optimal pada tanaman bawang merah secara nyata.

Perlakuan mulsa (M) yang berpengaruh nyata terhadap bobot umbi kering tanaman bawang merah ditunjukan pada Tabel 5.

Hasil uji BNJ pada taraf 5\% (Tabel 2), menunjukkan bahwa bobot umbi kering tanaman bawang merah tertinggi terjadi pada perlakuan mulsa kulit kakao (M2=144,3 g/rumpun) berbeda nyata dengan perlakuan tanpa mulsa $(93,6$ g/rumpun), perlakuan mulsa plastik (M3=98,2 g/rumpun) dan perlakuan mulsa jerami padi (M1=99,2 g/rumpun), ini berarti bahwa penggunaan mulsa kulit kakao dapat mengahasilkan bobot umbi kering yang optimal pada tanaman bawang merah secara nyata.

\section{PEMBAHASAN}

Berdasarkan analisis sidik ragam menunjukan tidak ada inetraksi antara pemberian berbagai jenis mulsa (M) dan berbagai jenis pupuk $(\mathrm{P})$ terhadap intensitas serangan hama $S$. exigua dan bobot umbi bawang merah.

Tidak terjadinya interaksi antara pemberian berbagai jenis pupuk dan berbagai jenis mulsa disebabkan karena pengaruh sederhana dari faktor-faktor yang di uji dalam penelitian ini sama besar. Hal ini berarti bahwa pengaruh beberapa jenis mulsa dan pengaruh beberapa jenis pupuk direspon sama besar oleh semua parameter yang diamati dalam penelitian ini.

Analisis ragam pemberian mulsa jerami padi (M1) menyebabkan penurunan intensitas serangan hama $S$. exigua ditunjukan pada (Tabel 1). Penggunaan mulsa jerami padi (M1) menyebabkan tingkat serangan hama $S$. exigua paling rendah dibandingkan perlakuan lainnya dan tingkat serangan paling tinggi pada perlakuan kontrol (M0).

Mulsa jerami padi dapat menurunkan intensitas serangan hama $S$. exigua sebesar 20,83\%. Hal ini karena mulsa jerami padi dapat menyebabkan peningkatan kelimpahan artropoda predator serangga hama pada tanaman bawang merah terutama artropoda predator kelompok laba-laba dan semut.

Pemberian mulsa jerami padi juga dapat meningkatkan populasi mikroartropoda tanah yaitu akari dan kolembola (Adisarwanto dan Wudianto, 1999). Hal ini disebabkan jerami padi mengandung nitrogen yang apabila dimanfaatkan sebagai mulsa akan mengalami proses dekomposisi oleh akari, kolembola, cendawan, dan bakteri. Organisme tersebut merupakan mangsa alternatif bagi artropoda predator antara lain kelompok semut (Aquino et al., 2002), laba-laba (Foelix, 1982), (Maloney et al., 2002), dan kumbang tanah (Aquino et al, 2002).

Hasil analisis ragam pemberian mulsa kulit kakao (M2) menyebabkan peningkatan hasil tanaman bawang merah (Tabel 2). Pemberian mulsa kulit kakao menyebabkan bobot umbi paling berat dibandingkan dengan mulsa lainnya dan yang paling rendah pada perlakuan kontrol. Mulsa kulit kakao dapat meningkatkan hasil bawang merah sebesar $47,61 \%$.

Terjadinya peningkatan bobot umbi tanaman bawang merah dengan pemberian mulsa kulit kakao karena mulsa kulit 
buah kakao bersifat sarang yang dapat mempertahankan temperatur serta kelembaban tanah dan memperkecil penguapan air tanah sehingga tanaman yang tumbuh pada tanah tersebut dapat hidup dengan baik sehingga akumulasi panas sebagai efek dekomposisi segera akan dapat ditranslokasikan ke udara dan akumulasi panas di bawah mulsa dapat teratasi (stabil).

Tingginya hasil produksi tanaman bawang merah yang diberi mulsa kulit buah kakao juga disebabkan distribusi asimilat tanaman lebih dikonsentrasikan pada pertumbuhan generatif dan kompetisi antara organ atau jaringan akan ditentukan oleh laju pengeluaran bahan dari pembuluh floem (phloem unloading) pada masingmasing organ tersebut. Wood (1989), menyatakan bahwa aerasi dalam tanah penting untuk respirasi akar dan untuk absorpsi nutrisi. Soedarsono et al., (1997) menambahkan bahwa dengan adanya mulsa kulit kakao struktur tanah menjadi remah dan gembur dan aerasi menjadi lebih baik. Menurut Soedarsono et al., (1997) mulsa kulit buah kakao juga dapat meningkatkan kadar hara dalam tanah yang akan dimanfaatkan oleh tanaman.

\section{KESIMPULAN}

Berdasarkan hasil pengamatan yang diperoleh dari penelitian ini dapat disimpulkan sebagai berikut :

1. Tidak ada pengaruh interaksi antara pemberian berbagai jenis mulsa dan pupuk terhadap penurunan intensitas serangan hama $S$. Exigua dan peningkatan bobot umbi bawang merah.

2. Pemberian berbagai jenis mulsa yang berbeda dapat menurunkan intensitas serangan hama S. exigua sebesar $20,83 \%$ pada perlakuan mulsa jerami padi dan dapat meningkatkan bobot umbi bawang merah sebesar $47,61 \%$ pada perlakuan mulsa kulit kakao.

3. Pemberian berbagai jenis pupuk yang berbeda tidak menurunkan serangan hama S. exigua dan tidak dapat meningkatkan bobot umbi bawang merah.

\section{DAFTAR PUSTAKA}

Adisarwanto dan Wudianto. 1999. Meningkatkan hasil panen kedelai di lahan Sawah, kering, dan pasang surut. Dalam Mariano, A. S. A. 2003. Pengaruh Pupuk Phonska dan Mulsa Jerami terhadap Beberapa Sifat Fisik Dan Kimia Tanah serta Produksi Kedelai (Glycine L Merr). Skripsi. Departemen Ilmu Tanah dan Sumberdaya Lahan. Fakultas Pertanian. IPB. Bogor.

Ahmad, Mushtaq, Abid Farid, and Muhammad Saeed. 2018. "Resistance to New Insecticides and Their Synergism in Spodoptera Exigua (Lepidoptera: Noctuidae) from Pakistan." Crop Protection 107 (May): 79-86. https://doi.org/10.1016/j.cropro.2017.12.028.

AquinoAT,MabesaRC.2002.Offseasonproductionofhoneydewmelon(CucumismeloL.)usingmulcha ndrowcover.PhilippineAgric.Sci.85(3):221-229.

Balaram Naik, A., and A. Chennakeshava Reddy. 2018. "Optimization of Tensile Strength in TIG Welding Using the Taguchi Method and Analysis of Variance (ANOVA)." Thermal Science and Engineering Progress 8 (December): 327-39. https://doi.org/10.1016/j.tsep.2018.08.005.

Chen, Jixiang, Weili Jiang, Hongyan Hu, Xiaoyan Ma, Qian Li, Xianpeng Song, Xiangliang Ren, and Yan Ma. 2019. "Joint Toxicity of Methoxyfenozide and Lufenuron on Larvae of Spodoptera Exigua Hübner (Lepidoptera: Noctuidae)." Journal of Asia-Pacific Entomology 22 (3): 795-801. https://doi.org/10.1016/j.aspen.2019.06.004.

Foelix, R.F. 1982. Biology of Spiders. HarvardUniversity Press. Cambridge. 306. 
Gautam, Shriniwas, Pepijn Schreinemachers, Md. Nasir Uddin, and Ramasamy Srinivasan. 2017. "Impact of Training Vegetable Farmers in Bangladesh in Integrated Pest Management (IPM)." Crop Protection 102 (December): 161-69. https://doi.org/10.1016/j.cropro.2017.08.022.

Githiomi, Caroline, Beatrice Muriithi, Patrick Irungu, Chris M. Mwungu, Gracious Diiro, Hippolyte Affognon, John Mburu, and Sunday Ekesi. 2019. "Economic Analysis of Spillover Effects of an Integrated Pest Management (IPM) Strategy for Suppression of Mango Fruit Fly in Kenya." Food Policy 84 (April): 121-32. https://doi.org/10.1016/j.foodpol.2019.03.006.

Haque, Ma, MA Monayem Miah, Ms Hossain, An Luna, and Ks Rahman. 2014. "Profitability of Garlic (Allium Sativum L.) Cultivation in Some Selected Areas of Bangladesh." Bangladesh Journal of Agricultural Research 38 (4): 589-98. https://doi.org/10.3329/bjar.v38i4.18944.

Kalmar, Evie, Susan L. Ivey, Asa Bradman, Victoria Leonard, and Abbey Alkon. 2014. "Implementing an Integrated Pest Management (IPM) Program in Child Care Centers: A Qualitative Study." Early Childhood Research Quarterly 29 (3): 245-54. https://doi.org/10.1016/j.ecresq.2014.02.005.

Limbongan, J. dan A. Monde. 1999. Pengaruh penggunaan pupuk organik dan anorganik terhadap pertumbuhan dan produksi bawang merah kultivar Palu. Jurnal Hortikultura 9 (3): 212-219.

Lu, Jiannan, and Alex Deng. 2017. "On Randomization-Based Causal Inference for Matched-Pair Factorial Designs." Statistics \& Probability Letters 125 (June): 99-103. https://doi.org/10.1016/j.spl.2017.02.007.

Maloney, D., F.A. Drummoud and R. Alford. 2002. Spider predation in agroecosystems:Can spiders effectively control pest population. Mafes Technical Bulletin 190:1-32.

Maskar, Basrum, A. Lasenggo, dan M. Slamet.2001. Uji multilokasi bawang merah Palu.Laporan Tahun 2001. Balai PengkajianTeknologi Pertanian Sulawesi Tengah, Palu.13 hlm..

Muriithi, Beatrice W., Hippolyte D. Affognon, Gracious M. Diiro, Sarah W. Kingori, Chrysantus M. Tanga, Peterson W. Nderitu, Samira A. Mohamed, and Sunday Ekesi. 2016. "Impact Assessment of Integrated Pest Management (IPM) Strategy for Suppression of MangoInfesting Fruit Flies in Kenya." Crop Protection 81 (March): 20-29. https://doi.org/10.1016/j.cropro.2015.11.014.

Mustafa, Ghazala, and Setsuko Komatsu. 2016. "Toxicity of Heavy Metals and Metal-Containing Nanoparticles on Plants." Biochimica et Biophysica Acta (BBA) - Proteins and Proteomics 1864 (8): 932-44. https://doi.org/10.1016/j.bbapap.2016.02.020.

Nielsen, Glenn Gunner Brink, Anders Kjær, Beate Klösgen, Per Lyngs Hansen, Adam Cohen Simonsen, and Bjarke Jørgensen. 2016. "Dielectric Spectroscopy for Evaluating Dry Matter Content of Potato Tubers." Journal of Food Engineering 189 (November): 9-16. https://doi.org/10.1016/j.jfoodeng.2016.05.011.

Nunes, Alexandro Silva, Vicente Paulo Campos, Alessandra Mascarello, Taisa Regina Stumpf, Louise Domenghini Chiaradia-Delatorre, Alan Rodrigues Teixeira Machado, Helvécio Martins Santos Júnior, Rosendo Augusto Yunes, Ricardo José Nunes, and Denilson Ferreira Oliveira. 2013. "Activity of Chalcones Derived from 2,4,5-Trimethoxybenzaldehyde against Meloidogyne Exigua and in Silico Interaction of One Chalcone with a Putative Caffeic Acid 3O-Methyltransferase from Meloidogyne Incognita.” Experimental Parasitology 135 (4): 66168. https://doi.org/10.1016/j.exppara.2013.10.003. 
Parrilla Vázquez, P., C. Ferrer, M.J. Martínez Bueno, and A.R. Fernández-Alba. 2019. "Pesticide Residues in Spices and Herbs: Sample Preparation Methods and Determination by Chromatographic Techniques." TrAC Trends in Analytical Chemistry 115 (June): 13-22. https://doi.org/10.1016/j.trac.2019.03.022

Pasaru, F. 1999. Prospek pengembangan agenhayati untuk pengendalian hama sayuran di Sulawesi Tengah. Prosiding Seminar NasionalHasil Pengkajian dan Penelitian TeknologiPertanian Menghadapi Era Otonomi Daerah,Palu, 3-4 November 1999. Pusat Penelitiandan Pengembangan Sosial Ekonomi Pertanian,Bogor. hlm. 138-142..

Raeisi, Sara, Majid Sharifi-Rad, Siew Young Quek, Bahareh Shabanpour, and Javad Sharifi-Rad. 2016. "Evaluation of Antioxidant and Antimicrobial Effects of Shallot (Allium Ascalonicum L.) Fruit and Ajwain (Trachyspermum Ammi (L.) Sprague) Seed Extracts in Semi-Fried Coated Rainbow Trout (Oncorhynchus Mykiss) Fillets for Shelf-Life Extension." LWT - Food Science and Technology 65 (January): 112-21. https://doi.org/10.1016/j.lwt.2015.07.064.

Rossi, Frank, and Viktor Mirtchev. 2016. "Analysis of Variance (ANOVA).” In Statistics for Food Scientists, 19-29. Elsevier. https://doi.org/10.1016/B978-0-12-417179-4.00004-4.

Saeed, Qamar, Faheem Ahmad, Naeem Iqbal, and Syed Muhammad Zaka. 2019. "Chemical Control of Polyphagous Pests on Their Auxiliary Hosts Can Minimize Insecticide Resistance: A Case Study of Spodoptera Exigua Hübner (Lepidoptera: Noctuidae) in Cotton Agroecosystem." Ecotoxicology and Environmental Safety 171 (April): 721-27. https://doi.org/10.1016/j.ecoenv.2019.01.038.

Satsijati dan E. Koswara. 1993. Studi penerapanformulasi teknologi budi daya bawang merahdan cabai di lahan pasang surut. JurnalHortikultura 3(1): 13-20

Soedarsono, Abdoellah, S., Aulistyowati..1997. penebaran kulit buah kakao sebagai sumber bahan organik tanah dan pengaruhnya terhadap produksi kakao. Pelita perkebunan 13 (2):90-99

Sutater, T., Satsijati, E. Koswara, D. Haryadi, dan Amaluddin. 1990. Daya hasil bawang merah di lahan pasang surut dan rawa. Risalah Hasil Penelitian Proyek Swamps II Bogor, 19-21 September 1989. BadanPenelitian dan Pengembangan Pertanian, Jakarta. hlm. 265-269.

Tarnawska, Monika, Agnieszka Babczyńska, Karolina Hassa, Alina Kafel, Anna Płachetka-Bożek, Jan Augustyniak, Marta Dziewięcka, Barbara Flasz, and Maria Augustyniak. 2019. "Protective Role of Zinc in Spodoptera Exigua Larvae under 135-Generational Cadmium Exposure." Chemosphere 235 (November): 785-93. https://doi.org/10.1016/j.chemosphere.2019.06.209.

Wang, Xuegui, Xing Xiang, Huiling Yu, Shuhua Liu, Yong Yin, Peng Cui, Yaqiong Wu, Jing Yang, Chunxian Jiang, and Qunfang Yang. 2018. "Monitoring and Biochemical Characterization of Beta-Cypermethrin Resistance in Spodoptera Exigua (Lepidoptera: Noctuidae) in Sichuan Province, China." Pesticide Biochemistry and Physiology 146 (April): 71-79. https://doi.org/10.1016/j.pestbp.2018.02.008.

Winter, Carl K, and Elizabeth A Jara. 2015. "Pesticide Food Safety Standards as Companions to Tolerances and Maximum Residue Limits." Journal of Integrative Agriculture 14 (11): 235864. https://doi.org/10.1016/S2095-3119(15)61117-0.

Wood, G.A.R. 1989. Cocoa. Third Edition. Longman Group Limited. London.

Wongmekiat, O., N. Leelarugrayub, and K. Thamprasert. 2008. "Beneficial Effect of Shallot (Allium Ascalonicum L.) Extract on Cyclosporine Nephrotoxicity in Rats." Food and Chemical Toxicology 46 (5): 1844-50. https://doi.org/10.1016/j.fct.2008.01.029. 